\title{
As A Supply Chain Financing Source, Trade Credit and Bank Credit Relationship during Financial Crises from Clustering Point of View
}

\author{
Cuneyt Sevim ${ }^{1}$, Aykut Ekiyor ${ }^{2}$, Ali Tosyali ${ }^{3,4}$ \\ ${ }^{1}$ Division of Economic Sciences, Turkish Military Academy, Ankara, Turkey \\ ${ }^{2}$ Faculty of Economics and Administrative Sciences, Gazi University, Ankara, Turkey \\ ${ }^{3}$ Department of Industrial and Systems Engineering, Rutgers University, New Jersey, USA \\ ${ }^{4}$ Department of Industrial and Systems Engineering, Turkish Military Academy, Ankara, Turkey \\ Correspondence: Cuneyt Sevim, Division of Economic Sciences, Turkish Military Academy, Bakanliklar, 06654, Ankara, \\ Turkey. Tel: 90-312-417-5190. E-mail:csevim@kho.edu.tr
}

\author{
Received: January 15, 2016 \\ Accepted: February 14, 2016 \\ Online Published: March 5, 2016 \\ doi:10.5539/ibr.v9n4p45 \\ URL: http://dx.doi.org/10.5539/ibr.v9n4p45
}

\begin{abstract}
This paper examines trade credit and bank credit behavior of firms during financial crisis using World Bank Survey dataset that contains detailed data on trade credit utilization of firms. Unlike literature, cluster analysis is used in order to investigate credit behavior of firms during financial crisis. For better clustering results, feature selection method is used to select variables thought to be important on model. When examined the trade and bank credit behavior of clusters that have been formed by using these variables with clustering analysis, it has been found that impact of the crisis on firms in the supply chain is important. It is found that due to demand fall for goods generated by crisis, firms are motivated to give trade credits to their customers in order not to lose them. However, firms need financial support either from the previous link in the supply chain through trade credit or from the financial institutions through bank credit.
\end{abstract}

Keywords: trade credit, bank credit, supply chain financing, financial crises

\section{Introduction}

Trade credit and bank credit are among the most important short-term financial sources of firms in the supply chain. These two external sources of finance are becoming increasingly important, especially in times of financial crisis. Sometimes trade credit, which can be described as postponement of the receivables from customers (account receivable) or suspension of the payment of debts to suppliers (account payable), is becoming more important than bank credit in the economies. At first glance, providing trade credit is not rational due to the loss of profits for the suppliers who postponed the receivables collection. By providing customers with trade credit, suppliers could be deprived of interest charges and offer an indirect discount to customers. The thing that these irrational behaviors are so common is the main reason that explains why researchers do a lot of studies in the field.

Studies show that it gets difficult for the firms to find trade credit and bank credit due to the negative effect of financial crises. Therefore, bank credit is complementary of trade credit. Some other studies, on the other hand suggest that when financial markets especially banking sector are severely affected by financial crises, trade credits become an important alternative financial source to the firms. In this situation, financial crises have positive effect on trade credits. Thus, bank credit and trade credit are substitute for each other.

After all, it is expected that financial crises affect supply chains via supply chain financing. However, current evidence in literature is not sufficient to conclude controversies related to effects of financial crises on bank credit and trade credit. During financial crises, some of the suppliers increase the amount of trade credit in order to protect long-term relationships. However, some suppliers that face the crisis at the first hand reflect the negative effect of the crisis to the previous units of the chain with an even accelerated way, which is called the bullwhip effect. On the other hand, because of the uncertainties caused by the financial crisis, there will be trust issues between the firms in the supply chains. Therefore, they will decrease their trade credit to their customers.

Considering analysis methods of the current studies, relationship between trade credit and bank credit have been examined mostly on country and sector basis. The purpose of this study, unlike literature, is to cluster firms according to their similarities, to observe firm behaviors on usage of trade and bank credit in the same cluster and then to reveal the 
reasons for different behaviors between clusters. In this study, 2009 Financial Crises Survey conducted by the World Bank after 2008 global financial crisis is used. Trade credit and bank credit behaviors of 1686 firms operate in Bulgaria, Hungary, Latvia, Lithuania, Romania and Turkey were analyzed using K-means clustering method. For better clustering results, variables thought to affect credit behavior of firms are selected using feature selection method. The degrees of importance of each variable and the dependent variable calculated by feature selection using Pearson chi-square test approach and then variables that have high explanatory power have been detected based on their p-values. As the most important factors affecting the credit behaviors are, respectively, sector of firm, if the firms consider reducing the number of employees due to financial crisis, whether firms apply for state aid during financial crisis or not, how sales are affected by crisis, the main effect of crisis on the firm, size of locality of the firm and finally whether firm is affected by crisis or not. When examined the trade and bank credit behavior of clusters that have been formed by using these factors with clustering analysis, it has been found that impact of the crisis on firms in the supply chain is important. According to analysis results, in order not to face demand fall for their products and lose their customers, firms that have been most adversely affected by the crisis provide more trade credit. However, to do this, they need bank credit from financial institutions and trade credit from their suppliers. This way, while firms that have been most adversely affected by the crisis need more bank credit and trade credit from financial institutions and from their suppliers, they give more trade credit to their customers. In this context, trade credit performs as a function to mitigate the destructive effects of the financial crisis and to solve the liquidity bottlenecks problem temporarily.

The paper is organized as follows: Section 2 summarizes the related work. Section 3 introduces the model used in this paper, Section 4 reports and discusses the results obtained. Section 5 summarizes the findings of the study and draws a conclusion for the whole research.

\section{Literature Review}

Two main sources in supply chain financing are bank credit and trade credit. Generally, trade credit is the postponement of payment for the goods purchased. As shown in Figure 1, trade credit has two aspects. One of them is postponement of receivables from customers (account receivable), the other is postponement of debt payments to the suppliers (account payable). "Trade credit is extended for the purchase of raw materials and other inputs. Bank credit consists of loan that a firm uses to finance ongoing operations; to finance seasonal or cyclical cash flow shortages; to finance start-up costs for new operations; to finance purchases, etc" (Chant \& Walker, 1988). Difficulty of understanding the determinants of financial relationship between firm within the supply chain and previous and subsequent chain ring at first glance has attracted many researchers. Does financial support provided through debt rescheduling contradict to homoeconomicus behavior in economics? Or are there economic reasons behind firms' these irrational behaviors? Studies looking for answers to these questions are summarized in this section.

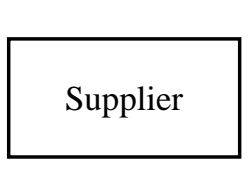

Goods or Services

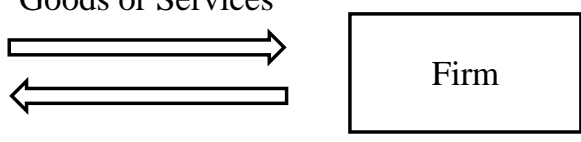

Delaying Payment

(Account Payable)

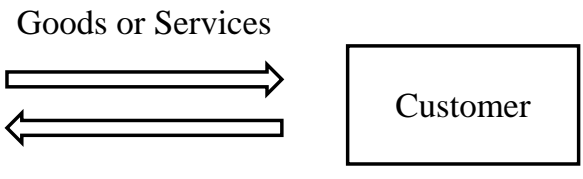

Delaying Payment

(Account Receivable)

Figure 1. Structure of Trade Credit (Tsuruta, 2013)

\subsection{Why Trade Credit?}

The most studied topic in literature is to investigate why trade credit is used. Based on the position of the firm in supply chain (supplier or customer), the answer to question, "Why trade credit?" will change. In the literature, the cause of trade credit is observed sometimes in terms of customer, sometimes in terms of supplier, and sometimes in terms of both customer and supplier. Therefore, in this section, thoughts and findings regarding to reasons of trade credit usage in the literature are summarized in supply-side and demand-side perspective.

\subsubsection{Supply Side Perspective}

With neo-classical economic approach, supply side perspective is associated with trade credit supply curve to shift to the right so as to increase sales. In other words, it is associated with account receivable as shown in Figure 1. By providing ease of payment, trade credit allows manufacturers to increase their sales without lowering the price of the goods they sell. Meltzer (1960) states that firms which stock funds during easy money periods use their accumulated balances as a resource of trade credit to other firms in the periods of tight money. They may also accelerate their sales using the credit policy instead of reducing prices during the tight money period. 
Motivation to increase sales with giving trade credit does not relate only to current sales but also to future sales. Petersen and Rajan (1996) argues that trade credit is a way of acquisition of new customers as well as protecting existing ones. In other words, firms are motivated to make long-term relationships with their customers by providing trade credit. Suppliers, compared to financial institutions and other suppliers have the ability to have information about their customers as they observe trade relations and debt habits of their customers that results in lower transaction costs. In addition, suppliers have the right to repossessing goods that they sell as collateral in trade credit and have the ability to encashment by selling them again. Due to this information and collecting power, suppliers can give credit easier than banks. Additionally, trade credit enables the price differentiation, which is one of the profit maximization tools in neo-classical economics. In this way, they are able to maximize their profits by selling goods with different prices to customers who have different elasticity (Petersen \& Rajan, 1996).

Luo and Zhang (2012) claim that trade credit is a new coordination tool for supply chain. Changing the trade credit based on order-quantity is much more beneficial for supply chain coordination. They state that customers who have long-term relationships with suppliers and strong credit record are qualified for trade credit. They claim that trade credit can be used to convince costumers to increase order quantity and is more attracting than discounts (Luo \& Zhang, 2012).

According to Schwarts (1974), trade credit is a financial source that provides agility to firms and started to be mentioned a lot in the literature. It protects firms and supply chains from economic fluctuations. Firms give trade credit because trade credit decreases uncertainty and simplifies cash management of firms by gaining time to be ready for the unexpected fluctuation of product demand.

Second question that comes to mind after understanding why firms give trade credit is why some firms give more trade credit compared to others. Hyndman and Serio (2010) explain that with the competitive environment in the market. If there is monopolistic market structure, the only firm in the market is not very keen on giving trade credit. Hyndman and Serio (2010) investigated the relationship between trade credit and competition and they found a $\cap$-shaped relation. The amount of trade credit increases sharply from monopoly to duopoly and gradually up to four competitors and decreases thereafter (Hyndman \& Serio, 2010). Klapper and Randal (2011) have also reached supporting empiric results. According to results, the more severe the crisis is, the less trade credit firms can get. However, the firms in more competitive markets can get more trade credits. According to authors, the most probable reason for this situation is that the firms in competitive markets try to attract new customers and avoid losing existing customers.

In another study to investigate why some firms give less trade credit, Tsurata (2013) suggests that suppliers decrease the amount of account payable to their customers that have high account receivable in the period of recession and have lower cash holdings. In other words, credit risk affects account payable. Suppliers monitor their customers. If they have too much account receivable in the period of recessions, suppliers regard this situation as high risk and thus reduce the amount of trade credit to customers. In addition, suppliers also reduce trade credit to firms that have lower cash holdings. However, if they do not foresee the future uncertainty they treat all customers in a distrustful manner and therefore don't give trade credit to the customers.

\subsubsection{Demand Side Perspective}

Demand side perspective is related to why firms demand trade credit. In other words, it is related to account payable as shown in Figure 1. Schwarts (1974) believes that financial benefits of trade credit are more than bank credit. Thus firms prefer trade credit to bank credit. According to Petersen and Rajan, one of the most important studies in this area is that there is a strong relationship between trade credit usage and availability. Compared to cost of credit, the difficulty with having access to bank credit have more effects on decisions to choose between bank credit and trade credit. Firms that cannot get credit from banks prefer trade credit. Petersen and Rajan (1994) investigated how relationship between firms and creditors (suppliers and banks) affects the availability and cost of funds to the firms. It is stated that relationship has smaller effect on cost but stronger effect on availability. The study shows that there is a relationship between credit availability and trade credit (Petersen \& Rajan 1994). Since small firms have more difficulties to access capital markets, they tend to use more trade credits. Therefore, they express that there is a negative relationship between trade credit demands and length of banking relationship (Petersen \& Rajan, 1997).

Danielson and Scott (2004) extend the studies of Petersen and Rajan and find that trade credit demand depends on credit availability which depends on length of banking relationship. Demand of firms for trade credits increases when banks impose credit constraints. When firms cannot make payments on time, the relationship between bank and firm suffers and credit availability decreases. Therefore, trade credits can be an expensive alternative to bank credits for firms. However, when firms make payments on time and keep strong relationship with banks trade credits can be complementary of bank credits. In addition, they stated that trade credits can be used as a long term financial source but they may be an expensive substitute for bank credits (Danielson \& Scott, 2004).

Wilner (2000) argues that firms prefer trade credit to bank credit due to the power of renegotiation of higher interest loans 
with suppliers because of strong relationships. Wilner (2000) studies how relationship between creditor and the firm affects the characteristic of lending. Credit interest rates get more negotiable when the creditor is more dependent on the firm. Larger renegotiation concessions not only induce less financially stable firms to prefer trade credit but also cause all companies to agree higher interest rates to get trade credit. On the other hand, creditors offer 'teaser rates' to appeal dependent customers and then increase rates during the negotiations (Wilner, 2000).

Howorth and Reber (2003) study another aspect in trade credit. They investigate habitual late payments in trade credit and according to their quantitative and qualitative data analysis of firms in UK, financial strength and customer relationships play an important role in late payments of trade credits. Howorth and Reber, (2003) in a research investigating if it becomes a pattern for small firms to make late payment of trade credit prove that some small firms use habitual late payment as a source of finance. Additionally, customer and supplier relationships are shown to be effective in the decision to pay late (Howorth \& Reber, 2003).

\subsection{Trade Credit - Bank Credit Relationship}

The second most studied subject in the literature is the direction of the relationship between trade credit and bank credit. Table 1 shows that in some studies there is a complementary relationship, in some studies there is a substitute relationship, and in some studies it is shown that there are both complementary and substitute relationship between trade credit and bank credit on different conditions. The literature is summarized in this context in this section.

Table 1. Trade Credit and Bank Credit Relationship

\begin{tabular}{lll}
\hline Complementary & Substitute & Complementary and Substitute \\
\hline Meltzer (1960) & Petersan and Rajan (1997) & Danielson and Scott (2004) \\
Ono (2001) & Wilner (2000) & Love et al. (2007) \\
Love and Zaidi (2010) & Nilsen (2002) & Yang (2011) \\
& Fishman and Love (2003) & \\
& Chor and Manova (2012) & \\
& Bastos and Pindado (2013) & \\
\hline
\end{tabular}

Meltzer (1960), one of the pioneering studies in this area, emphasize that finding loans is associated with firm size. Since lenders prefer large firms to lend money rather than small firms, large firms may find both trade credit and bank credit more easily during tight money periods. Therefore, for large firms, both trade credit and bank credit increase whereas trade credit and bank credit for small firms decrease. Thus, relationship between trade credit and bank credit is positive and described as complementary relationship as expressed before

Ono (2001), who investigates account payable of firms that operate in manufacturing industry only, claims that nontransactional factors affect the amount of trade credits as well as transactional factors including future business prospects. When monetary policies work, it affects not only capital market but also trade credits (Ono, 2001). Therefore, trade credits are complementary of bank credits.

Love and Zaidi (2010) investigate trade credit behavior during 1998 financial crisis in four Asian countries for small and medium firms. They find that there is no substitute relationship between trade credits and bank credits. During financial crisis the firms that are in financial distress receive less trade credit, have shorter time for repayments and have to pay higher cost. As a result, the amount of both trade credit and bank credit decrease during financial crisis.

Petersen and Rajan (1997), which focuses on small firms that have challenges to enter the capital market, argues that in case firms cannot find credit from financial institutions, they tend do use more trade credit. Trade credit is used to minimize the overall transaction costs in the short term whereas it is accepted as a last resort in medium term. For this reason, according to Petersen and Rajan (1997), trade credit is a substitute for bank credit.

Wilner (2000), which draws attention to the dependency relationship between the customer and trade creditor, claims that strong relationship will lead creditors to make more concessions to customers especially during financial crisis. Thus amount of trade credit will increase even though bank credit decreases.

According to Nilsen (2002), trade credit is an alternative source of finance for small firms. Interestingly, this situation is true for large firms, too. If small or large firms experience a downturn in the finance they need fund from banks, they meet this requirement with trade credit.

According to Fishman and Love (2003) trade credit is a substitute of bank credit because of less developed financial market structure. If the development of the financial market in the country is not sufficient, firms tend to use more trade credit (Fishman \& Love, 2003).

Chor and Manova (2012) investigate the effect of global financial crisis on foreign trade using industry based USA commercial data and found that industries which use more trade credits show good export performance. This result emphasizes importance of trade credit in supply chain in period of financial crisis that create shortage in the external 
financial source. In this situation trade credit and bank credit are substitute for each other.

Bastos and Pindado (2013) study trade credit during financial crisis. They examine 147 firms from Argentina, Brazil, and Turkey and find that trade credit and bank credit substitute for each other. This paper support that while suppliers delay collection of payments from their customers, they try to get long-term trade credit from their suppliers. Thus, trade credit increases from both aspects during financial crisis.

Danielson and Scott (2004) link complementary and substitution relationship to rules, and consider the relationship between trade credit and bank credit from availability aspect as Petersen and Rajan (1997) does. However, Danielson and Scott (2004) say that banks measure trade credibility of firms by using volume of trade credit. They are not willing to give credit to firms that have a lot of credit debt. If firms make timely debt payments, banks regard this as positive signal and give credit. In case trade credit and bank credit has complementary relationship, there is substitution relationship for firms with high credit debt.

According to Love et al. (2007), firms give less credit to fragile financial firms during financial crisis. Even though trade credit increases during peak of the financial crisis, a financial crisis originated by the contraction of bank credit will not be able to compensate for the long term. Therefore, trade credit will be reduced during crisis. In other words, even though the relationship between trade credit and bank credit substitute for each other in the short term, there is a complementary relationship in the long-term.

Yang (2011) studies the relationship between trade credit and bank credit in 2008 financial crisis and finds that bank credit and trade credit are both complementary and substitutes for each other. The reason behind this is that while account receivable is decreasing, account payable is increasing. Bank credit decreases sharply after the crisis and continues to decrease in three quarters. However, account receivable increases right after crisis and then starts to decrease. Account payable increases during and after crisis.

\subsection{Advantages and Disadvantages of Trade Credit}

One of the most popular topics in literature is investigation of advantage and disadvantage of trade credit. The first thing that comes to mind is information advantage. The most important issue for creditors is to know the habit of timely debt payments of their customers. They may need to bear a lot of cost to get this information. Trade creditors have opportunity to get this information at a lower cost. Suppliers visit their customers more frequently than financial institutions. The amount and time of orders give an idea about the status of a customer. If customers cannot use the opportunity to benefit from the discount by paying their debts early, this gives a negative signal to supplier about the status of customer. Financial institutions also may get the same information but it may take more time and be more expensive (Petersen \& Rajan, 1997). Thus, asymmetric information between borrower and lender is less in the case of trade credit than in the case of bank credit.

Trade credit gives more deterrent force to firms in the collection of the debt. Perhaps due to the nature of the commodity markets, there are often few alternative supply sources. So in case customers cannot pay their debts on time, supplier may threaten to cut the supply of goods. This threat is more effective on customers with a small share in total sales of supplier. However, the power of financial institutions on this issue is rather limited. Threatening to cut future financial supply is not effective as cutting the supply of goods (Petersen \& Rajan, 1997).

Despite the deterrent force, trade creditors that are unable to collect their debts may take their goods back from customers if the sector is not service sector. This means a good guarantee of the debt especially for durable goods. Undoubtedly, financial institutions can confiscate these goods in return but they may not encash the goods as quick as suppliers because they are not familiar with the market of these goods and do not have the ability to sell at a higher value (Petersen \& Rajan, 1997). Trade creditors have the advantage of the same collection to cash very quickly and without loss of value. In other words, the ability of trade creditors to cash goods easily provides a liquidity advantage.

If suppliers' profit margin and the price elasticity of demand are high, trade credit may be an effective price discrimination tool. While high cost of trade credit supports riskier customers, customers with a high credibility of trade credit will pay back their debts right away as they find it expensive. Thus, the same goods will be sold at different prices to customers with different credibility (Petersen \& Rajan, 1997).

On the other hand, trade credit provides a transaction cost advantage. Monthly or quarterly payments, rather than payments on each delivery, decreases the amount of transaction costs. Therefore, delivery schedule and payment cycle is organized separately from each other (Petersen \& Rajan, 1997). It also saves time on quality control, make inventory management easier, and strengthen long-term customer supplier relationship (Aktas et al., 2012).

Trade credit may provide advantages for the macro economy in addition to micro-economic advantages listed above. Ferris (1981) emphasizes that trade credit as a substitute for money, accelerates the flow of real and financial value. This means that trade credit may bring vitality to the economy. Firms that find credits from financial institutions easily 
offer more trade credit to their customers. Thus, with the possibility of borrowing from financial institutions, firms mediate to ones without possibility. Therefore, from macro-economic perspective, trade credit supports the resolution of liquidity problems in the economy and contribute seriously to the developing economies that have more fragile structures (Bastos \& Pindado, 2012).

One of the potential disadvantage of trade credit is that opportunity cost of offering trade credit is high. Allowing customers to delay the payment of trade credit leads to a loss of profits for firms. In other words, they are deprived of interests that they can collect (Petersen \& Rajan, 1997).

Another disadvantage relates to the spread of financial crisis. Trade credit causes a strong link that improves relationship between firm and customers. In this way, trade credit performs as financial intermediary Due to similar structure, financial crisis spreads in supply chains because of trade credit in the same way of financial institutions (Danielson \& Scott, 2004; Kiyotaki \& Moore, (1997, 2002); Tsuruta, 2013).

\section{Methodology}

In this study, trade credit and bank credit behavior of firms during financial crisis is investigated with clustering approach instead of investigating in country base. It is assumed that firms that are similar to each other behave similar during financial crisis. In this aspect each cluster investigated separately.

In the proposed method, feature selection, which is also known as variable selection, is used for selecting relevant variables into subsets. The objectives of utilizing feature selection are to make us understand and explicate the model, to decrease training times and to increase generalization by variance reduction in statistics and machine learning. Some techniques are used in feature selection; however, we have chosen Pearson's chi-square technique as it is the most frequently used test and allow us to discover whether there are relationships among variable categories. Pearson's chi-squared test presents importance of independent variables in our proposed approach.

After calculating and determining importance of variables, K-means method builds the clusters in the presented methodology. K-means clustering method, which was mentioned by MacQueen (1967), is used to separate a data set into $\mathrm{k}$ groups. The main advantage of K-means method is its simplicity to solve clustering problems with large datasets. This method is used to classify data in accordance with similar features to build clusters. The focal point is to determine $\mathrm{k}$ cluster centers. K-means method tries to minimize an objective function, in which a squared error function measures squared distance between a data point and the cluster center iteratively.

In this study, Clementine Software has been used for both K-means clustering and feature selection algorithms. A brief diagram of the proposed methodology can be seen in Figure 2 and high-level steps of proposed method are as follows:

Step 1. Choose variables from the Enterprise Financial Crisis Survey

Step 2. Calculate the importance of independent variables by Feature Selection using Pearson $\chi^{2}$ test approach

Step 3. Determine the important independent variables based on p-values

Step 4. Build the cluster by using important independent variables by K-Means Method

Step 5. Compare the clusters to understand firm credit behavior

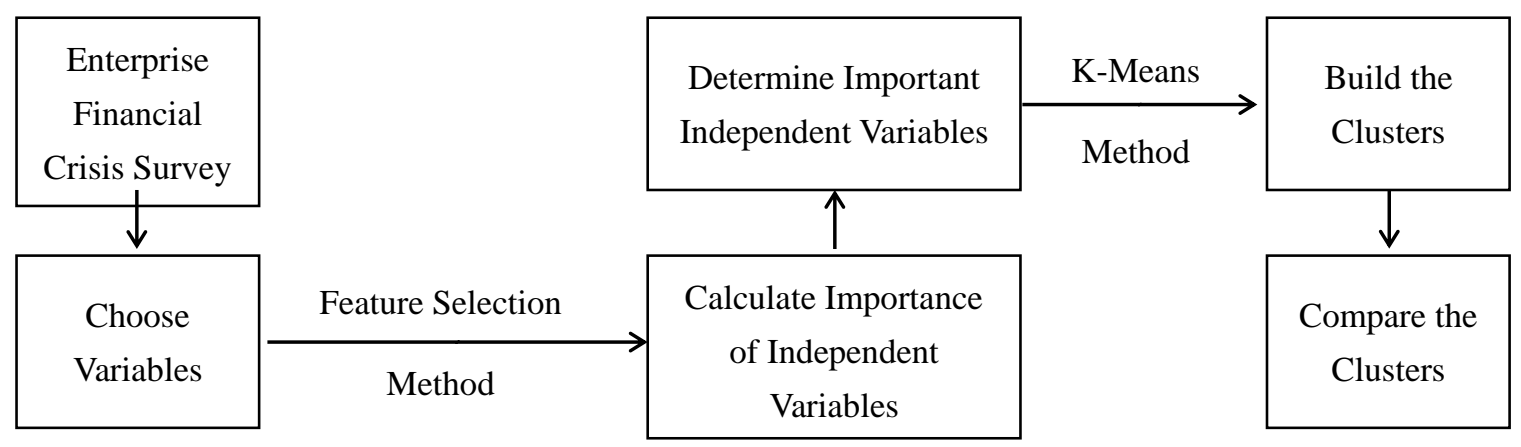

Figure 2. The flowchart for the proposed methodology

\section{Results and Discussions}

In this section, according to methodology outlined in Figure 2, analysis results will be discussed. First, data set and significance of the variables calculated based on feature selection is shared and clusters that have been formed with $\mathrm{K}$-means clustering method is discussed. 
Data comes from the Enterprise Financial Crisis Survey, which is conducted in 2009 by The World Bank. The survey covers 1686 firms in both manufacturing and service sectors from Turkey, Romania, Hungary, Latvia, Lithuania, and Bulgaria. The survey includes topics that are affected by financial crisis such as sales, employment, finances and R\&D. Samplings cover small, medium, and large firms from nonagricultural private economy.

Questions to analyze trade credit and bank credit, which are shown in Table 2, have been selected by taking literature into account. From the World Bank Survey, 15 questions are used as the determinant of the credit usage and 3 questions are used as the dependent variables. In Table 2, d1, d3, and d5 stand for account receivable, account payable, and bank credit usage, respectively. For d5, it is converted to "yes or no" question. If there is 0 in the answer, it means "No, I didn't use bank credit", otherwise it means "Yes, I used bank credit".

Table 2. Independent and Dependent Variables

\begin{tabular}{|c|c|c|}
\hline $\mathrm{Nu}$. & Label & Independent Variables \\
\hline 1. & a0 & Country \\
\hline 2. & a3 & Size of locality \\
\hline 3. & $\mathrm{a} 4 \mathrm{c}$ & Sector \\
\hline 4. & $\mathrm{a} 6 \mathrm{~b}$ & Firm size \\
\hline 5. & b1a & $\begin{array}{l}\text { If you compare this establishment's sales for the last completed month in } 2009 \text { with the same month in } \\
2008 \text {, how did they change? }\end{array}$ \\
\hline 6. & $\mathrm{~b} 2 \mathrm{a}$ & What do you expect will happen with this establishment's sales one year from now? \\
\hline 7. & b4 & $\begin{array}{l}\text { In the last completed month, what was this establishment's output in comparison with the maximum } \\
\text { output possible using all resources available (capacity utilization)? }\end{array}$ \\
\hline 8. & $\mathrm{c} 1$ & $\begin{array}{l}\text { At the end of the last completed month, how many permanent, full-time employees did this } \\
\text { establishment employ? Please include all employees and managers }\end{array}$ \\
\hline 9. & c1a & $\begin{array}{l}\text { Does this establishment plan to reduce the number of permanent full-time employees in the next } 6 \\
\text { months due to the financial crisis? }\end{array}$ \\
\hline 10. & $\mathrm{c} 2$ & How many full-time temporary employees worked in this establishment in the last 6 months? \\
\hline 11. & e1 & Has the financial crisis affected this establishment? \\
\hline 12. & e2 & $\begin{array}{l}\text { Choosing from the following list what has been the main effect the financial crisis on this } \\
\text { establishment? }\end{array}$ \\
\hline 13. & e3 & $\begin{array}{l}\text { Has the establishment filed for reorganization that is revaluing the value of the assets to reflect their } \\
\text { actual market value, during the last } 12 \text { months? }\end{array}$ \\
\hline 14. & e4 & Has the establishment filed for insolvency or bankruptcy during the last 12 months? \\
\hline 15. & $\mathrm{e} 5$ & Has this establishment applied for direct state aid in the last 12 months? \\
\hline $\mathrm{Nu}$. & Label & Dependent Variables \\
\hline 1. & d1 & In the last completed month, did this establishment sell goods or services on credit? \\
\hline 2. & d3 & $\begin{array}{l}\text { In the last completed month, did this establishment delay payments for more than one week to tax } \\
\text { authorities or suppliers? }\end{array}$ \\
\hline 3. & d5 & $\begin{array}{l}\text { In the last completed month please estimate the proportion of this establishment's working capital that } \\
\text { was financed from banks? }\end{array}$ \\
\hline
\end{tabular}

Pearson chi-square test approach is used in order to identify the most influential variables. Cutoff values to distinguish the importance of variables are 0.95 and 0.90 . Variables with p-value greater than 0.95 and 0.90 are assigned as important and marginal, respectively as shown in Table 3 . When carefully examined, it is obvious to see in Table 3 that the most effective factors on trade credit usage are the sector in which firm operates; how the number of workers working affected from crisis; whether firm applied for state aid during crisis or not; how crisis affected the sales; in which aspect of crisis affects firm; size of locality; and finally whether firm has been affected by crisis or not. The main determinants of trade credit behavior relate to crisis and how firms are affected by this crisis. It is obvious to see that county of firm is not an important factor. Therefore, in order to understand the credit behavior of firms, clustering analysis is used rather than country based analysis. 
Table 3. Feature Selection Analysis Results

\begin{tabular}{|c|c|c|c|c|}
\hline Rank & Label & Variables & Importance & p-values \\
\hline 1 & $\mathrm{a} 4 \mathrm{c}$ & Sector & Important & 0.99 \\
\hline 2 & c1a & $\begin{array}{l}\text { Does this establishment plan to reduce the number of permanent } \\
\text { full-time employees in the next } 6 \text { months due to the financial crisis? }\end{array}$ & Important & 0.99 \\
\hline 3 & e5 & Has this establishment applied for direct state aid in the last 12 months? & Important & 0.99 \\
\hline 4 & b1a & $\begin{array}{l}\text { If you compare this establishment's sales for the last completed month in } \\
2009 \text { with the same month in } 2008 \text {, how did they change? }\end{array}$ & Important & 0.99 \\
\hline 5 & e2 & $\begin{array}{l}\text { Choosing from the following list what has been the main effect the } \\
\text { financial crisis on this establishment? }\end{array}$ & Important & 0.99 \\
\hline 6 & a3 & Size of locality & Important & 0.97 \\
\hline 7 & e1 & Has the financial crisis affected this establishment? & Marginal & 0.91 \\
\hline 8 & b4 & $\begin{array}{l}\text { In the last completed month, what was this establishment's output in } \\
\text { comparison with the maximum output possible using all resources } \\
\text { available (capacity utilization)? }\end{array}$ & Unimportant & 0.89 \\
\hline 9 & $\mathrm{~b} 2 \mathrm{a}$ & $\begin{array}{l}\text { What do you expect will happen with this establishment's sales one year } \\
\text { from now? }\end{array}$ & Unimportant & 0.81 \\
\hline 10 & $\mathrm{c} 1$ & $\begin{array}{l}\text { At the end of the last completed month, how many permanent, full-time } \\
\text { employees did this establishment employ? Please include all employees } \\
\text { and managers }\end{array}$ & Unimportant & 0.76 \\
\hline 11 & $\mathrm{a} 0$ & Country & Unimportant & 0.54 \\
\hline 12 & e3 & $\begin{array}{l}\text { Has the establishment filed for reorganization that is revaluing the value } \\
\text { of the assets to reflect their actual market value, during the last } 12 \\
\text { months? }\end{array}$ & Unimportant & 0.53 \\
\hline 13 & $\mathrm{c} 2$ & $\begin{array}{l}\text { How many full-time temporary employees worked in this establishment } \\
\text { in the last } 6 \text { months? }\end{array}$ & Unimportant & 0.42 \\
\hline 14 & $a 6 b$ & Firm Size & Unimportant & 0.14 \\
\hline 15 & e4 & $\begin{array}{l}\text { Has the establishment filed for insolvency or bankruptcy during the last } \\
12 \text { months? }\end{array}$ & $\begin{array}{l}\text { Screened } \\
\text { field Single } \\
\text { category too } \\
\text { large }\end{array}$ & - \\
\hline
\end{tabular}

15 variables have been examined and the most influential 7 variables have been used for clustering analysis and then trade credit behavior has been evaluated based on these resulting clusters. All firms included in the analysis have been clustered in 3 clusters using K-means clustering method. We choose $\mathrm{K}=3$ based on the number of firms belong to each cluster. According to results, Cluster-1, Cluster-2, and Cluster-3 contain 667, 574, and 445 firms, respectively. Clustering analysis results are shown in Table 4.

Using the data summarized in Table 4, in order to put forth the cluster characteristics, each variable has been tried to explain by graphics. Figure 3 shows the differentials between clusters in terms of locality. As seen in Figure 3, Cluster-2 has a larger percentage of population of firms that operate in major cities compared to other clusters. Cluster-1 and Cluster-3 consists of firms operating in relatively smaller cities. 
Table 4. Summary Statistics of Clusters (\%)

\begin{tabular}{lrrrr}
\hline & & Cluster-1 & Cluster-2 & Cluster-3 \\
\hline Size of locality & & & \\
& & & 12 & 29 \\
& Capital city & 10 & 52 & 9 \\
& Population over 1 million & 15 & 13 & 13 \\
& Over 250.000 to 1 million & 21 & 9 & 20 \\
& 50.000 to 250.000 & 27 & 14 & 30 \\
\hline Sector & Less than 50.000 & & 100 & 27 \\
& Manufacturing & 0 & 44 \\
& Other & 68 & 0 & 29 \\
\hline
\end{tabular}

If you compare this establishment's sales for the last completed month in 2009 with the same month in 2008 , how did they change?

\begin{tabular}{rrrr} 
Increased & 10 & 18 & 2 \\
Remained the same & 19 & 21 & 5 \\
Decreased & 69 & 59 & 91 \\
Don't know & 2 & 1 & 1 \\
\hline
\end{tabular}

Does this establishment plan to reduce the number of permanent full-time employees in the next 6 months due to the financial crisis?

\begin{tabular}{lrrrr} 
& Yes & 0 & 5 & 82 \\
& No & 99 & 91 & 0 \\
\hline Has the financial crisis affected this establishment? & Don't know & 1 & 4 & 18 \\
\hline & & & & \\
& Yes & 88 & 82 & 99 \\
& No & 11 & 18 & 1 \\
\hline
\end{tabular}

Choosing from the following list what has been the main effect the financial crisis on this establishment?

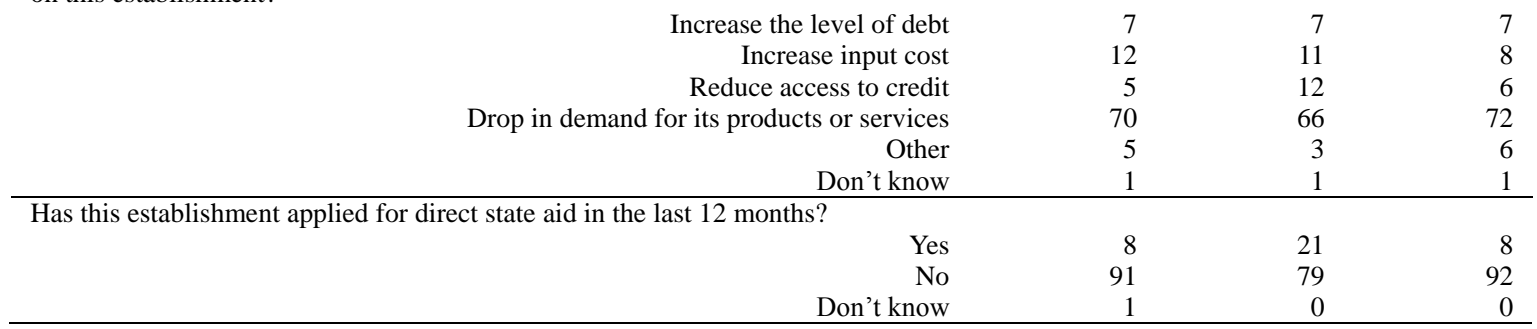

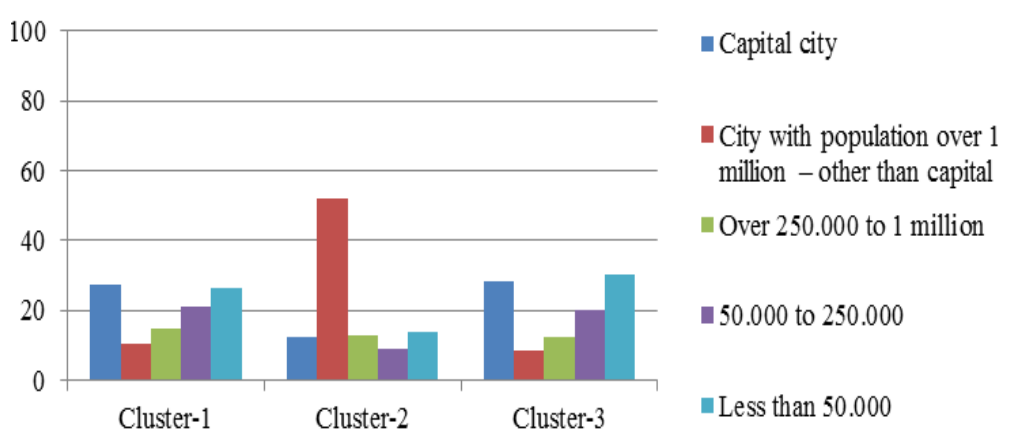

Figure 3. Size of locality (\%)

Figure 4 shows the differences between clusters in terms of sectors. Cluster- 2 appears to be the intensity of the firms operating in the manufacturing sector. In Cluster-1, intensity of firms operating in services and other sectors is obvious. There is no firm operating in the manufacturing sector. Cluster- 3 consists of firms from all sectors.

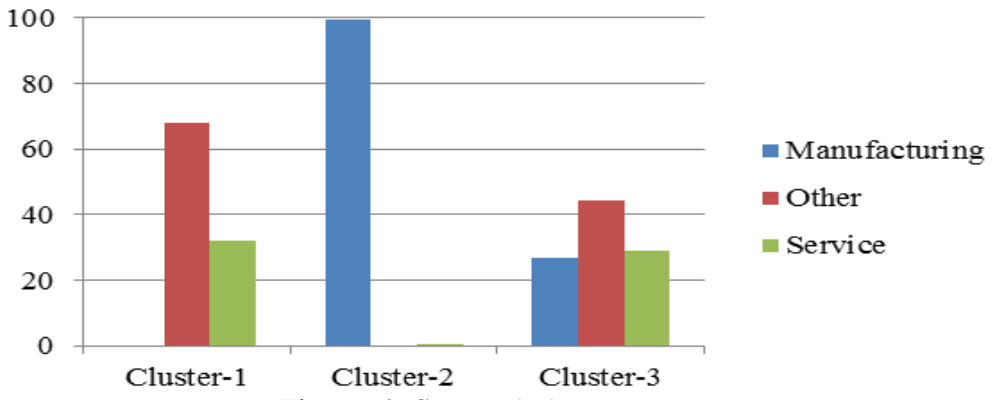

Figure 4. Sector $(\%)$ 
Figure 5 shows the comparisons of clusters based on post-crisis sales. It can be seen that in 2009 overall sales decrease after crisis compared to the same month of 2008. Cluster- 3 consists of firms that are affected from crisis relatively more. Cluster-1 is relatively less adversely affected and Cluster- 2 is said to be the least affected one in terms of sales.

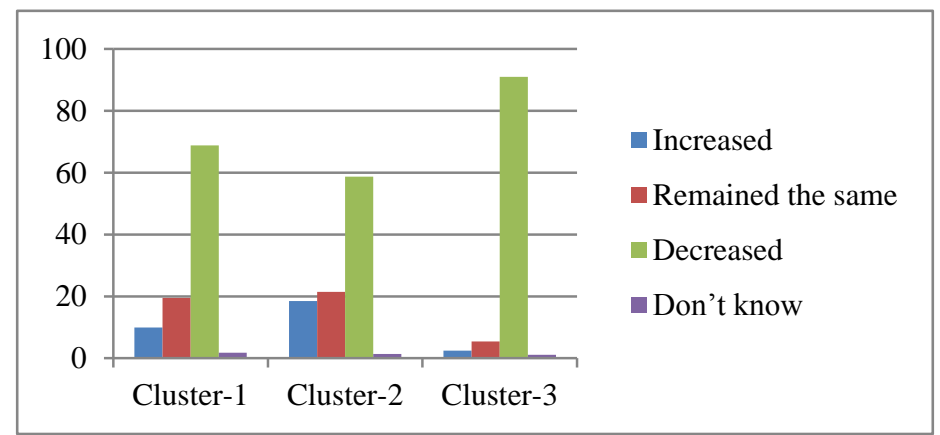

Figure 5. If you compare this establishment's sales for the last completed month in 2009 with the same month in 2008 , how did they change? $(\%)$

In Figure 6, it is shown that whether firms have permanent employee decals in the future 6-month period due to financial crisis or not. Due to the crisis, firms plan to decrease the number of workers most in Cluster-3, little in Cluster-2, and none in Cluster-1. Since Cluster-3 consists of firms that plan to decal most, Cluster-3 seems to be most adversely affected by crisis.

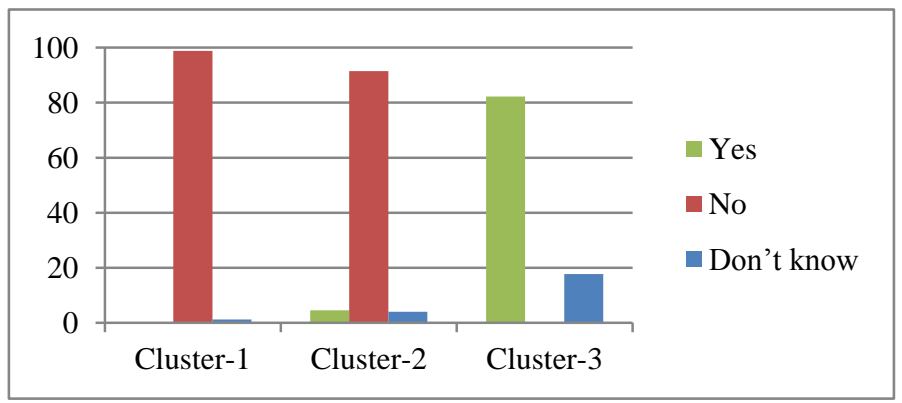

Figure 6. Does this establishment plan to reduce the number of permanent full-time employees in the next 6 months due to the financial crisis? $(\%)$

Figure 7 shows the comparisons of clusters based on the answers to the question "Is your firm affected by financial crisis?" An overall evaluation is seen that most of the firms have been affected by the crisis. When evaluated based on the clusters, it is seen that firms that are affected most from crisis belong to Cluster- 3 and firms that belong to Cluster- 1 and Cluster-2 affected relatively less from crisis.

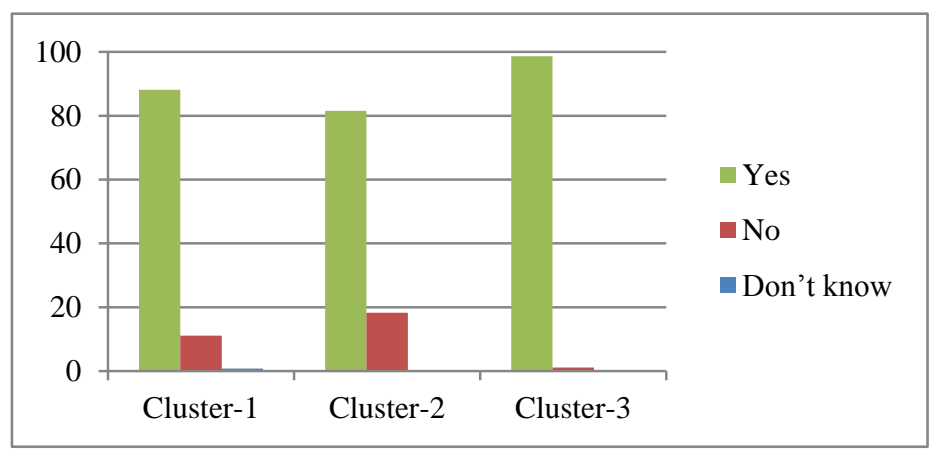

Figure 7. Has the financial crisis affected this establishment? (\%)

Direction of effect in financial crisis is shown in Figure 8. Generally, the main effect of crisis is the decrease of demand to firm's products. Cluster-3 may be said that it consists of firms that are relatively more affected in this regard. 


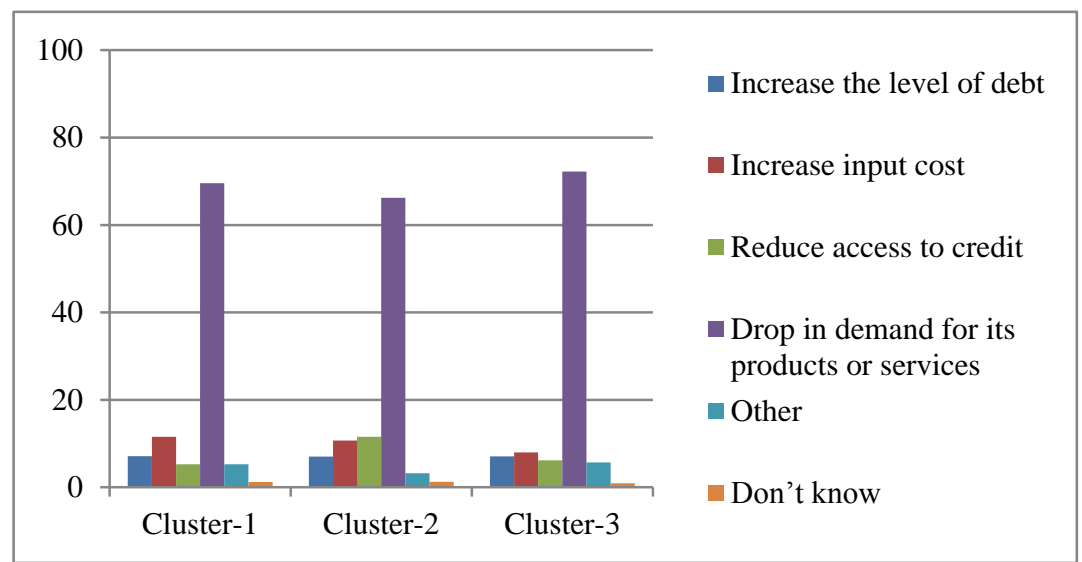

Figure 8. Choosing from the following list what has been the main effect the financial crisis on this establishment? (\%)

Comparisons of clusters according to the state aid during financial crisis are shown in Figure 9. Generally, it is seen that most of the firms didn't take state aid and all of the firms that used state aid are adversely affected firms. Number of firms that used state aid is highest in Cluster-2, relatively less in Cluster-1 and Cluster-3.

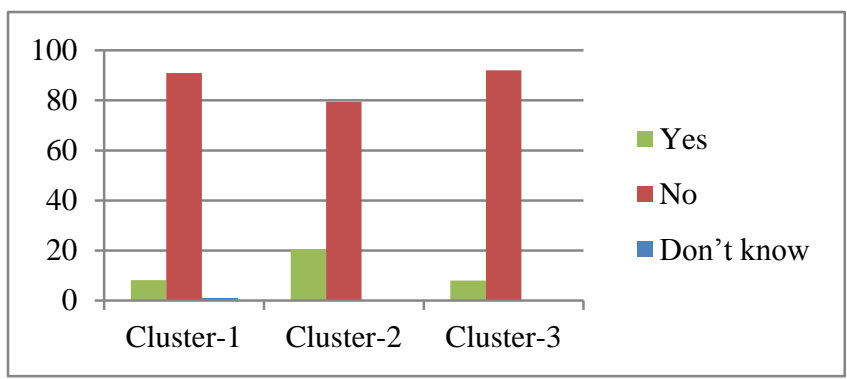

Figure 9. Has this establishment applied for direct state aid in the last 12 months? (\%)

One can summarize the clusters based on all 7 variables as follows:

- Firms belong to Cluster-1 operate in all sectors except the manufacturing sector; $37 \%$ of firms operate in major cities; $69 \%$ of firms faced sales fall; none of the firms consider employee decal; $88 \%$ of firms are adversely affected by crisis and $70 \%$ of them state demand fall as the reason; $8 \%$ of firms used state aid.

- All of the firms belong to Cluster-2 operate in manufacturing sector. $62 \%$ of firms operate in major cities; $59 \%$ of them faced sales fall; $5 \%$ considers employee decal; $82 \%$ state are adversely affected by crisis and $66 \%$ of them state demand falls as the reason; $21 \%$ used state aid.

- $73 \%$ of firms that belong to Cluster-3 are in the sectors other than the manufacturing sector and operate in relatively less populated cities. $91 \%$ of them faced sales fall, $82 \%$ considers employee decal, $99 \%$ have been adversely affected by crisis and state demand fall as the reason, $8 \%$ used state aid.

Account receivable, account payable and bank credit utilization percentages related to financial crisis period are shown in Table 5. As shown in Table 5, 33\% of firms belong to Cluster-1 use bank credit, 38\% of them use account payable, and $39 \%$ of them use account receivable during financial crisis. $31 \%$ of firms belong to Cluster- 2 use bank credit, $26 \%$ of them delay the payments to their suppliers, and 39\% of them give trade credit to their customers. $35 \%$ of firms belong to Cluster-3 use bank credit, $37 \%$ of them use account payable, and $52 \%$ of them give trade credit to their customers.

Table 5. Usage of Credit in Clusters (\%)

\begin{tabular}{lccc}
\hline & Cluster-1 & Cluster-2 & Cluster-3 \\
\hline Account Receivable & 39 & 39 & 52 \\
Account Payable & 38 & 26 & 37 \\
Bank Credit & 33 & 31 & 35
\end{tabular}

In the light of the results shown above, firms that belong to Cluster-3 are adversely affected most from crisis. Cluster-1 is following Cluster-3 in this aspect. The least affected ones by crisis are firms belong to Cluster-2. When examined the 
relationship between bank and trade credit utilization and the impact of crisis on the basis of clusters, one may see when number of firms that use credit increase, effect of crisis increases. Firms in Cluster-3 that is adversely affected most by crisis are seen to use more account receivable. Likewise, bank credit utilization percentage is also high for this cluster. Cluster- 2 consists of firms that are adversely affected less by crisis and use less credit.

These results are considered to be supportive due to the demand fall for goods generated by crisis; firms are motivated to give trade credits to their customers in order not to lose customers. However, in order to provide this financial transfer, firms need the previous link in the supply chain to provide trade credit and financial institutions to provide bank credit. In a sense, in order to maintain its presence, on the one hand firm uses trade credit and bank credit, on the other hand it give trade credit to its customers. In this context, trade credit performs as a function to mitigate the destructive effects of the financial crisis and to solve the liquidity bottlenecks problem temporarily.

\section{Conclusion}

This study has addressed trade credit and bank credit behavior of firms during financial crisis. The World Bank Survey in 2009 that consists of data on trade credit utilization of 1686 firms in Turkey, Romania, Hungary, Latvia, Lithuania, and Bulgaria is used for this problem. This paper proposes a methodology to investigate firms' behavior on using credit throughout financial crisis. The proposed methodology presents five steps for this purpose: choosing variables from survey, calculating importance of independent variables by feature selection method, determining important independent variables, building the clusters by using k-means method and comparing the clusters. Feature selection method that uses Pearson's chi-square test provides the most important seven ones among 15 variables. Then, all firms have been clustered into three clusters. When examined these three clusters, the effect of trade credit and bank credit behavior of firms is cracked up to be important during financial crisis. As the firms don't want to lose their customers, the firms tend to give trade credits to them owing to decreasing demand for goods and need to use bank credit from financial institutions. Consequently, the firms in the supply chain require trade credit from the previous link and provide trade credits to their customers to reduce the devastating effects of financial crisis.

\section{Acknowledgement}

The first author would like to thank to TUBITAK (The Scientific and Technological Research Council of Turkey) for the research scholarship grant supporting his work at Rutgers University as a visiting scholar.

\section{References}

Aktas, N., De Bodt, E., Lobez, F., \& Statnik, J. C. (2012). The information content of trade credit. Journal of Banking \& Finance, 36(5), 1402-1413. http://dx.doi.org/10.1016/j.jbankfin.2011.12.001

Bastos, R., \& Pindado, J. (2013). Trade credit during a financial crisis: A panel data analysis. Journal of Business Research, 66(5), 614-620. http://dx.doi.org/10.1016/j.jbusres.2012.03.015

Chant, E. M., \& Walker, D. A. (1988). Small business demand for trade credit. Applied Economics, 20(7), 861-876. http://dx.doi.org/10.1080/00036848800000012

Chor, D., \& Manova, K. (2012). Off the cliff and back? Credit conditions and international trade during the global financial crisis. Journal of International Economics, 87(1), 117-133. http://dx.doi.org/10.1016/j.jinteco.2011.04.001

Danielson, M. G., \& Scott, J. A. (2004). Bank loan availability and trade credit demand. Financial Review, 39(4), 579-600. http://dx.doi.org/10.1111/j.0732-8516.2004.00089.x

Ferris, J. S. (1981). A transactions theory of trade credit use. The Quarterly Journal of Economics, 243-270. http://dx.doi.org/10.2307/1882390

Fisman, R., \& Love, I. (2003). Trade credit, financial intermediary development, and industry growth. The Journal of Finance, 58(1), 353-374. http://dx.doi.org/10.1111/1540-6261.00527

Hastie, Trevor, Tibshirani, R., \& Friedman, J. (2009). The elements of statistical learning: data mining, inference, and prediction. Springer. http://dx.doi.org/10.1007/BF02985802

Howorth, C., \& Reber, B. (2003). Habitual late payment of trade credit: an empirical examination of UK small firms. Managerial and Decision Economics, 24(6-7), 471-482. http://dx.doi.org/10.1002/ mde.1128

Hyndman, K., \& Serio, G. (2010). Competition and inter-firm credit: Theory and evidence from firm-level data in Indonesia. Journal of Development Economics, 93(1), 88-108. http://dx.doi.org/10.1016/ j.jdeveco.2009.04.004

Kiyotaki, N., \& Moore, J. (1997). Credit chains. Journal of Political Economy, 105(21), 211-248. http://dx.doi.org/10.1086/262072 
Kiyotaki, N., \& Moore, J. (2002). Balance-sheet contagion. American Economic Review, 46-50. http://dx.doi.org/10.1257/000282802320188989

Kiyotaki, N., \& Moore, J. (2002). Evil is the root of all money. American Economic Review, 62-66. http://dx.doi.org/10.1257/000282802320189014

Klapper, L., \& Randall, D. (2011). Financial crisis and supply-chain financing. Trade Finance, 73.

Love, I., Preve, L. A., \& Sarria-Allende, V. (2007). Trade credit and bank credit: Evidence from recent financial crises. Journal of Financial Economics, 83(2), 453-469. http://dx.doi.org/10.1016/ j.jfineco.2005.11.002

Love, I., \& Zaidi, R. (2010). Trade Credit, Bank Credit and Financial Crisis. International Review of Finance, 10(1), 125-147. http://dx.doi.org/10.1111/j.1468-2443.2009.01100.x

Luo, J., \& Zhang, Q. (2012). Trade credit: A new mechanism to coordinate supply chain. Operations Research Letters, 40(5), 378-384. http://dx.doi.org/10.1016/j.orl.2012.04.008

MacQueen, J. (1967). Some methods for classification and analysis of multivariate observations. In Proceedings of the fifth Berkeley symposium on mathematical statistics and probability (Vol. 1, No. 14, pp. 281-297).

Meltzer, A. H. (1960). Mercantile credit, monetary policy, and size of firms. The Review of Economics and Statistics, 429-437. http://dx.doi.org/10.2307/1925692

Nilsen, J. H. (2002). Trade Credit and the Bank Lending Channel. Journal of Money, Credit, and Banking, 34(1), 226-253. http://dx.doi.org/10.1353/mcb.2002.0032

Ono, M. (2001). Determinants of trade credit in the Japanese manufacturing sector. Journal of the Japanese and International Economies, 15(2), 160-177. http://dx.doi.org/10.1006/jjie.2001.0466

Petersen, M. A., \& Rajan, R. G. (1994). The benefits of lending relationships: Evidence from small business data. The journal of finance, 49(1), 3-37. http://dx.doi.org/10.1111/j.1540-6261.1994.tb04418.x

Petersen, M. A., \& Rajan, R. G. (1996). Trade Credit: Theories and Evidence (No. w5602). National Bureau of Economic Research. http://dx.doi.org/10.3386/w5602

Petersen, M. A. (1997). Trade Credit: Theories and Evidence. The Review of Financial Studies, 10(3), 661-691. http://dx.doi.org/10.1093/rfs/10.3.661

Schwartz, R. A. (1974). An economic model of trade credit. Journal of financial and quantitative analysis, 9(04), 643-657. http://dx.doi.org/10.2307/2329765

Tsuruta, D. (2013). Credit contagion and trade credit: evidence from small business data in Japan. Asian Economic Journal, 27(4), 341-367. http://dx.doi.org/10.1111/asej.12018

Wilner, B. S. (2000). The exploitation of relationships in financial distress: The case of trade credit. Journal of Finance, 153-178. http://dx.doi.org/10.1111/0022-1082.00203

Yang, X. (2011). The role of trade credit in the recent subprime financial crisis. Journal of Economics and Business, 63(5), 517-529. http://dx.doi.org/10.1016/j.jeconbus.2011.05.001

\section{Copyrights}

Copyright for this article is retained by the author(s), with first publication rights granted to the journal.

This is an open-access article distributed under the terms and conditions of the Creative Commons Attribution license (http://creativecommons.org/licenses/by/3.0/). 